\title{
The Holocene palaeoceanographic history of Muck Deep, Hebridean shelf, Scotland: has there been a change of wave climate in the past 12000 years?
}

\author{
JOHN W. MURRAY \\ School of Ocean and Earth Science, Southampton Oceanography Centre, European Way, Southampton SO14 3ZH, UK.
}

\begin{abstract}
Depressions (known as deeps) on the Scottish continental shelf are sediment sinks and they, thus, provide important sources of information on past oceanography and climate. Muck Deep is a partially infilled relict glacial valley cut in the continental shelf. A $70 \mathrm{~cm}$ core shows an upper buff sandy mud layer (0-4500 BP, radiocarbon years) overlying a dark grey mud layer (4500-12 $000 \mathrm{BP})$. The foraminiferal faunas suggest that the upper sandy layer formed under higher energy conditions comparable to those existing now, where storm waves from southwesterly gales are responsible for transporting material from the adjacent shelf into the deeps. The grey mud formed under lower energy conditions as a consequence of lower storm wave influence on the sea floor (therefore, reduced transport of tests from the shelf into the deep). Because of the interaction of changing sea-levels and glacial rebound, water depths over Muck Deep were $35 \mathrm{~m}$ greater at $14-15 \mathrm{ka}$ and have never been less than now. Therefore, the likely explanation of the lower energy deposits at the base of the core is related to the impact of storm waves on sediment transport from the adjacent shelves. Either water depths over the adjacent shelves were too great to be influenced by storm waves or the wave climate (direction) differed at that time. J. Micropalaeontol. 23(2): 153-161, November 2004.
\end{abstract}

\section{INTRODUCTION}

The aim of this study is to reconstruct the Holocene palaeoceanographic history of Muck Deep (a depression adjacent to the isle of Muck) based on the foraminiferal record of a $70 \mathrm{~cm}$ long core.

The topography of the continental shelf to the west of Scotland is the most variable of the whole UK continental shelf. It has been moulded by erosional processes, including glacial scour, and by depositional processes, where sediments have buried the bedrock. Topographic highs are found where Precambrian basement or Tertiary igneous rocks outcrop, whereas the deeper areas $(>200 \mathrm{~m})$ were developed by glacial erosion of areas underlain by softer Mesozoic sedimentary rocks. During the last (Devensian) glaciation, the ice sheet reached an elevation of $c .700 \mathrm{~m}$ on Rhum and ice flow lines ran from east to west (Ballantyne, 1999). Over the shelf there was interaction between climatically induced eustatic changes of sea-level and isostatic changes due to crustal loading and unloading during ice build-up and subsequent melting (Lambeck, 1995). Former ice-scoured depressions on the shelf are now elongate basins filled with $>200$ m Quaternary deposits (Fyfe et al., 1993), while others, such as Muck Deep (maximum water depth $320 \mathrm{~m}$ ), were incompletely filled. In the vicinity of Muck Deep, the Quaternary deposits are represented by the Jura Formation which is well-layered acoustically and consists of dark grey silty clays with pebbles and shell fragments. This is a marine deposit as it contains marine foraminifera and dinoflagellates. In the type area (near Jura), warm and cold intervals have been recognized from this microfossil evidence (Binns et al., 1974; Fyfe et al., 1993). The lower warm interval may represent the Alleröd interstadial; the cold interval, the Loch Lomond readvance; and the upper warm interval represents Holocene conditions. Peacock \& Harkness (1990) concluded that 'Warming at the beginning of the Holocene Interglacial in the NE Atlantic may have taken place in two phases during the first of which, from 10,100 BP (radiocarbon years) to possibly
9,600 BP, the water temperature around Scotland was a little lower than at present.'

The latter comment is probably based on the presence of Elphidium clavatum in a borehole off Lewis. Formerly, this species was interpreted as a cold-water indicator but this clearly is not true as its distribution extends into temperate waters on both sides of the North Atlantic (Murray, 1991). At present, seasonal thermal stratification is normal over the Hebridean shelf (Lee \& Ramster, 1981). It has been suggested that in the Celtic Sea seasonal thermal stratification developed from around 9000 BP (Austin \& Scourse, 1997; Scourse et al., 2002).

Overlying the Jura Formation is a thin cover of recent sediments. In muddy areas, there is no clear separation between the modern sediments and the underlying late to postglacial clays (Fyfe et al., 1993). This paper reports a more detailed analysis of the microfossil record of this transition.

\section{MATERIALS AND METHODS}

\section{Sampling}

The location of the coring station (MD6) was $56^{\circ} 48.9^{\prime} \mathrm{N}, 06^{\circ}$ $40.5^{\prime} \mathrm{W}$, approximately $25 \mathrm{~km}$ west of the island of Muck, on the Hebridean shelf, Scotland (Fig. 1) at a water depth of 167-172 m. Cores were collected from the $R V$ Challenger on 6 June 1999 using a controlled descent gravity corer, with a $10 \mathrm{~cm}$ diameter core tube of $1 \mathrm{~m}$ length (Pedersen et al., 1985) and a hydraulically damped multicorer (Barnet et al., 1984) which took cores of $6 \mathrm{~cm}$ diameter with a penetration depth of approximately $22 \mathrm{~cm}$. The appearance of the long core as it was examined through the clear core tube immediately after retrieval was as follows (with depths from the sediment surface): $0-20 \mathrm{~cm}$, buff sandy mud becoming non sandy; $20-35 \mathrm{~cm}$, buff mud; 35-70 cm dark-grey mud (Julian Overnell, pers. comm.). The core was extruded and sliced to yield two slices $0.5 \mathrm{~cm}$ thick, $0.0-0.5 \mathrm{~cm}, 0.5-1.0 \mathrm{~cm}$, followed by $1 \mathrm{~cm}$ thick slices at $1-2 \mathrm{~cm}$, $2-3 \mathrm{~cm}$ and so on down to $19-20 \mathrm{~cm}$, followed by $24-25 \mathrm{~cm}$, 


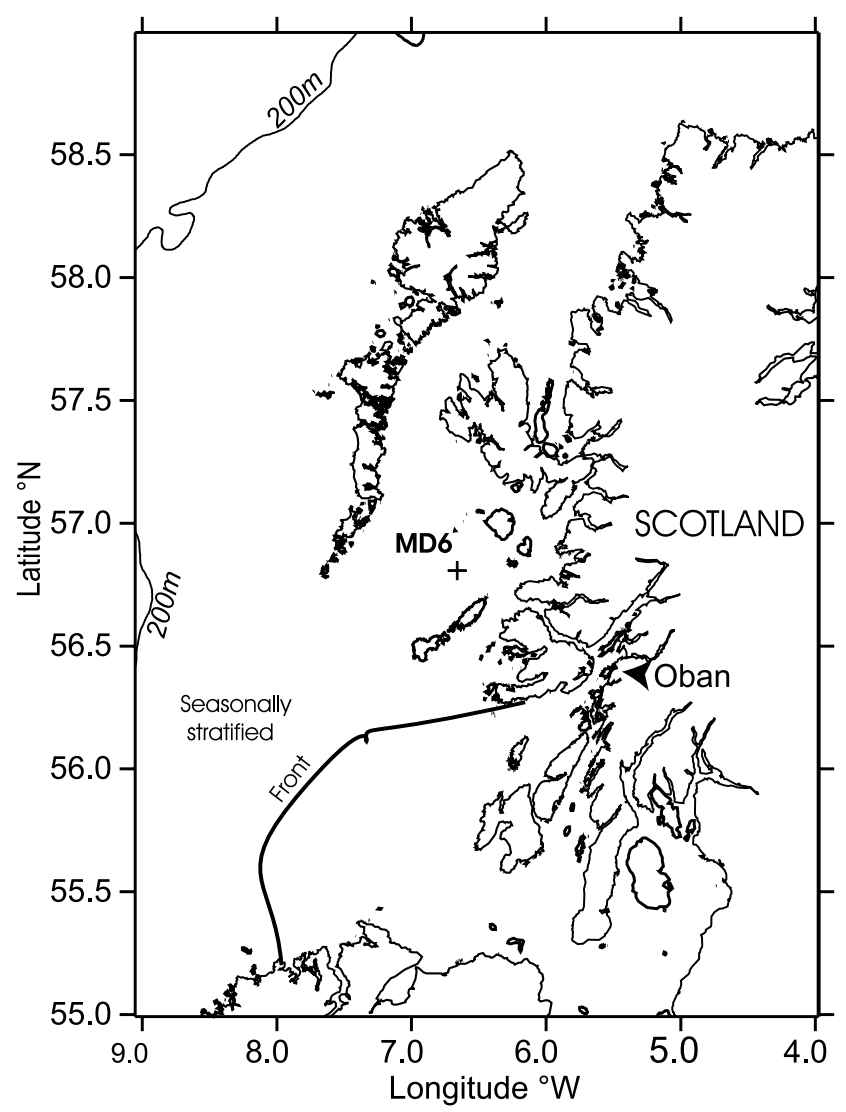

Fig. 1. Map of northwest Scotland showing the position of the sampling site, MD6, and the front separating seasonally stratified waters to the north and west from unstratified waters to the south (after Lee \& Ramster, 1981).

29-30 $\mathrm{cm}$ and so on down to $70 \mathrm{~cm}$. The $6 \mathrm{~cm}$ diameter core was similarly sliced down to $20 \mathrm{~cm}$ and frozen at $-20^{\circ} \mathrm{C}$ until required. The $10 \mathrm{~cm}$ core sliced sections were transferred to polythene bags and stored temporarily at $4{ }^{\circ} \mathrm{C}$.

\section{Grain size}

The samples were wet sieved into $>63 \mu \mathrm{m}$ and $<63 \mu \mathrm{m}$ fractions; both the fine and coarse fractions were then dried and the latter was dry sieved through $2 \mathrm{~mm}, 1 \mathrm{~mm}, 500 \mu \mathrm{m}, 250 \mu \mathrm{m}$ and $125 \mu \mathrm{m}$, followed by weighing the retained residues and the final filtrate.

\section{Foraminifera}

In the laboratory the samples were washed over a $63 \mu \mathrm{m}$ sieve, dried in an oven at $50^{\circ} \mathrm{C}$, cooled and weighed. The foraminifera were concentrated by flotation in trichloroethylene. In order to obtain a sub-sample of adequate size for picking, the flotations were divided by quartering. The residue was also checked for foraminifera. For the majority of samples a count of at least 250 individuals was made (Table 1). The generic assignments follow those of Loeblich \& Tappan (1987). Sources of taxonomic data include Haynes (1973), Höglund (1947), Murray (1971, 2003a fauna illustrated) and Williamson (1858). Commonly used univariate measures of species diversity have been calculated: Fisher alpha index and the information function $\mathrm{H}(\mathrm{S})$ (Murray,
1991). The mode of life has been divided into two groups: attached/clinging forms may remain anchored in one spot for most of the time; free-living forms are able to migrate through the sediment. In general, attached/clinging forms are epifaunal (Murray, 2003a). Comparison between the living and dead assemblages has been made using the Bray-Curtis index of similarity (Bray \& Curtis, 1957). For each sample pair, the lower $\%$ value for each species is summed. Identical samples have $100 \%$ Bray-Curtis similarity. The proportion of planktonic tests was calculated from $(P / P+B) \times 100$ where $P$ is planktonic and $B$ is benthic numbers of tests. Multivariate analysis (cluster analysis, covariance-based Principal Components Analysis (PCA) and non-metric Multidimensional Scaling (MDS)) was carried out using the Primer package (Clarke \& Gorley, 2001). Both cluster analysis and MDS make use of the similarity matrix based on Bray-Curtis similarity with no transformation of the data.

The samples from the surface to $20 \mathrm{~cm}$ were of known volume but of unknown weight since they were processed from the wet state so that they could be stained to determine the presence or absence of living forms. However, the density was measured on separate sub-samples and used to calculate the number of benthic foraminifera per $\mathrm{g}$ sediment $(\mathrm{BF} \mathrm{g})$. The samples from deeper than $20 \mathrm{~cm}$ were of known weight but of unknown volume.

\section{Stable isotopes}

Because of the faunal change down core, it was not possible to analyse a single species throughout. Stable isotopes of Bulimina marginata and Elphidium excavatum were analysed at Southampton Oceanography Centre using a Europa Geo 20-20 mass spectrometer equipped with a 'CAPS' automatic carbonate preparation system. Results are reported relative to Vienna Pee Dee Belemnite standard (VPDB). Standard external analytical precision, based on replicate analysis of in-house standards calibrated to NBS-19, is better than $0.1 \%$ for $\delta^{18} \mathrm{O}$ and $\delta^{13} \mathrm{C}$.

\section{AMS dates}

Three samples were selected for dating to determine the age of the base of the core and the timing of the faunal change in the middle section of the core (Table 2). The analyses were carried out by Leibniz Labor für Altersbestimmung und Isotopenforschung, Christian-Albrechts-Universität, Kiel, Germany. The tests were cleaned with $30 \% \mathrm{H}_{2} \mathrm{O}_{2}$ in an ultrasonic bath to remove adhering dust and detrital carbonate as well as organic surface coating, washed with water and dried. The samples were cleaned again with $15 \% \mathrm{H}_{2} \mathrm{O}_{2}$ in an ultrasonic bath and pumped to vacuum while still wet. The $\mathrm{CO}_{2}$ was liberated from each sample with $100 \%$ phosphoric acid at $90^{\circ} \mathrm{C}$. The sample $\mathrm{CO}_{2}$ was reduced with $\mathrm{H}_{2}$ over about $2 \mathrm{mg}$ of $\mathrm{Fe}$ powder as catalyst, and the resulting carbon/iron mixture was pressed into a pellet in the target holder. The ${ }^{14} \mathrm{C}$ concentration of the samples was measured by comparing the simultaneously collected ${ }^{14} \mathrm{C},{ }^{13} \mathrm{C}$, and ${ }^{12} \mathrm{C}$ beams of each sample with those of Oxalic Acid standard $\mathrm{CO}_{2}$ and Eemian foraminifera. Conventional ${ }^{14} \mathrm{C}$ ages were calculated with a $\delta^{13} \mathrm{C}$ correction for isotopic fractionation (according to Stuiver \& Polach, 1977) based on the ${ }^{13} \mathrm{C} /{ }^{12} \mathrm{C}$ ratio measured by the AMS system simultaneously with the ${ }^{14} \mathrm{C} /{ }^{12} \mathrm{C}$ ratio. For the determination of measuring uncertainty (standard 
Palaeoceanographic history of Muck Deep, Scotland

\begin{tabular}{|c|c|c|c|}
\hline 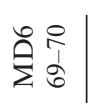 & 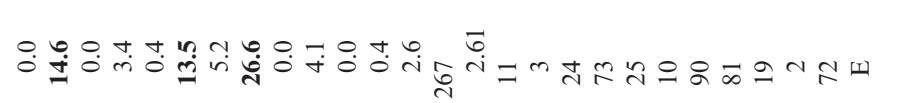 & $\begin{array}{ll}\stackrel{0}{\sigma} & \stackrel{0}{\infty} \\
i & \stackrel{i}{i}\end{array}$ & \\
\hline 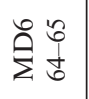 & 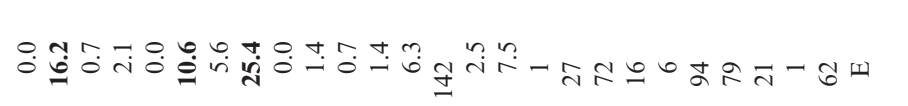 & $\underset{\substack{i \\
i}}{\stackrel{\infty}{n}}$ & \\
\hline 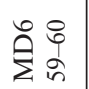 & 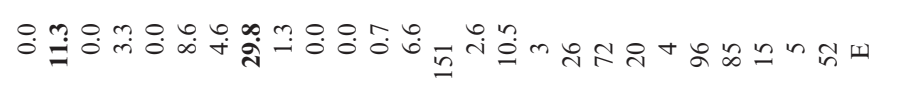 & & \\
\hline t & 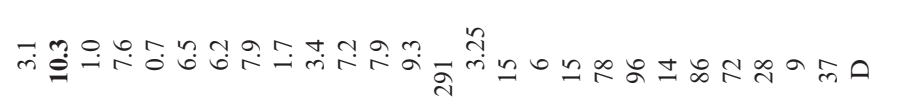 & 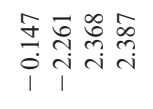 & \\
\hline 8 & 무요 & 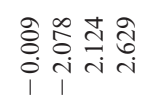 & \\
\hline 7 & 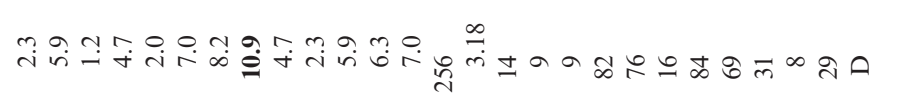 & 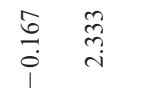 & \\
\hline g & 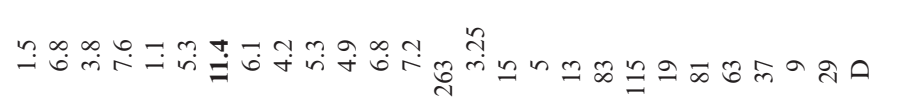 & 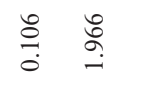 & \\
\hline If & 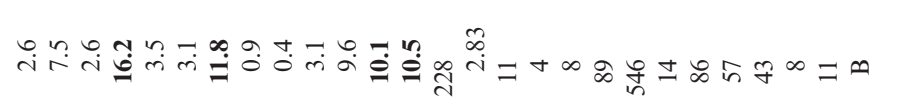 & $\underset{0}{\stackrel{0}{0}} \stackrel{\circ}{\circ}$ & \\
\hline 5 & 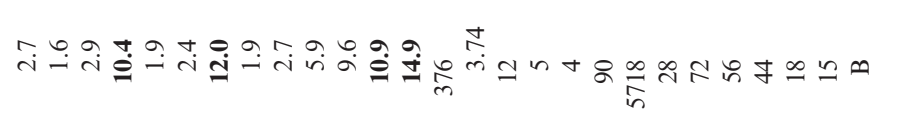 & $\stackrel{\infty}{\infty} \stackrel{\infty}{\circ}$ & \\
\hline I & 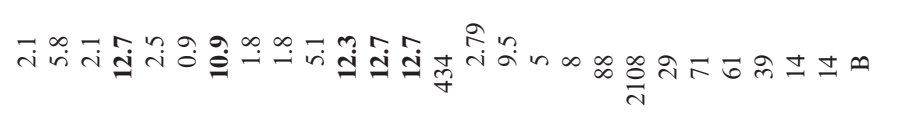 & 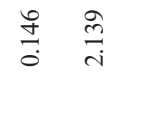 & \\
\hline 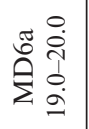 & 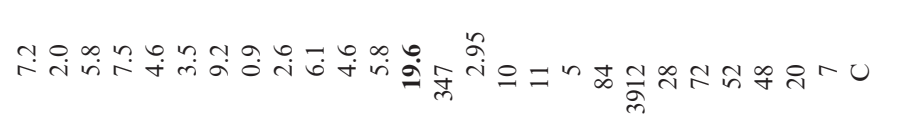 & $\stackrel{\substack{0 \\
0}}{\stackrel{m}{i}}$ & \\
\hline $\begin{array}{l}0 \\
0 \\
i \\
i\end{array}$ & 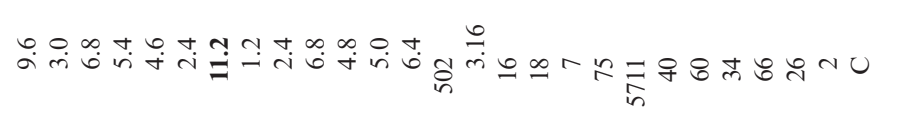 & $\stackrel{\overbrace{}}{\stackrel{n}{c}} \stackrel{\infty}{\infty}$ & \\
\hline 尚 & 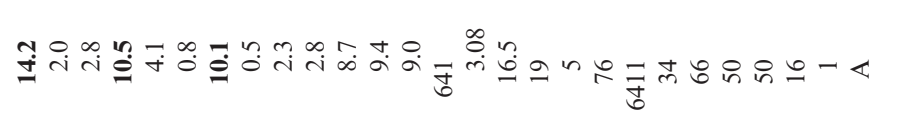 & 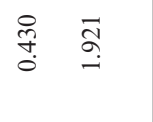 & \\
\hline i. & î & 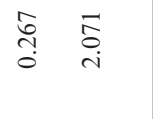 & \\
\hline 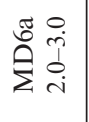 & 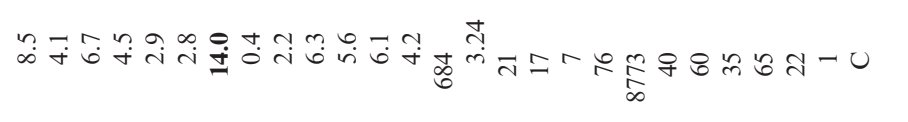 & 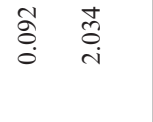 & \\
\hline ì & 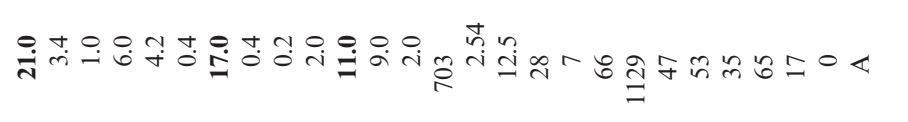 & 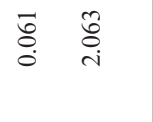 & \\
\hline 10 & 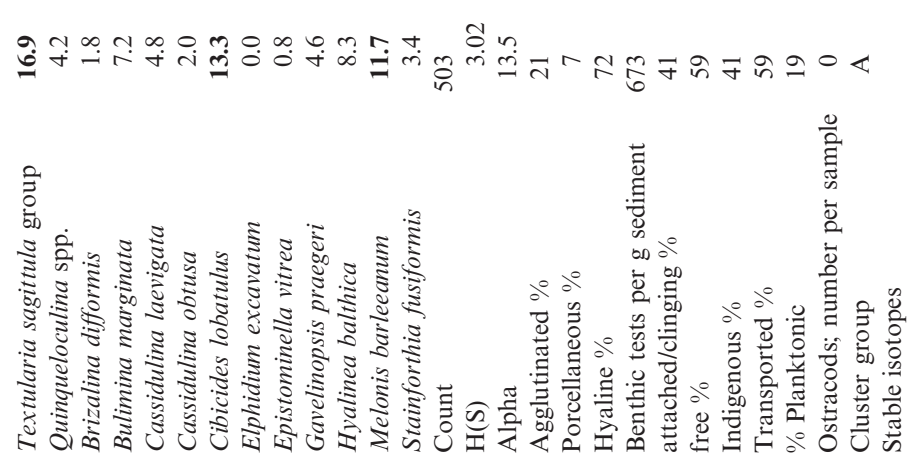 & 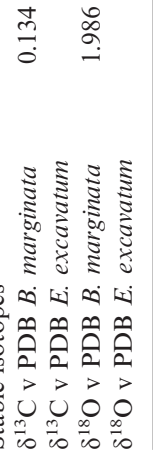 & 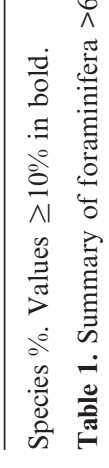 \\
\hline
\end{tabular}




\begin{tabular}{lccrr}
\hline Sample & $\begin{array}{c}\text { Depth } \\
(\mathrm{cm})\end{array}$ & Material & $\begin{array}{c}\text { Corrected } \\
\text { pMC }\end{array}$ & $\begin{array}{c}\text { Radiocarbon } \\
\text { years bp }\end{array}$ \\
\hline KIA 21407 & $64-65$ & Yodiella tomlini + fragments & $20.22 \pm 0.21$ \\
KIA 23063 & $34-35$ & Timoclea ovata & $57.11 \pm 0.24$ & $12840 \pm 80$ \\
KIA 23064 & $29-30$ & juvenile bivalve shells & $68.50 \pm 0.26$ \\
\hline
\end{tabular}

Sample code given by the laboratory. Corrected pMC indicates the percent of modern (i.e. 1950) carbon corrected for fractionation using the ${ }^{13} \mathrm{C}$ measurement.

Table 2. Details of AMS dates.

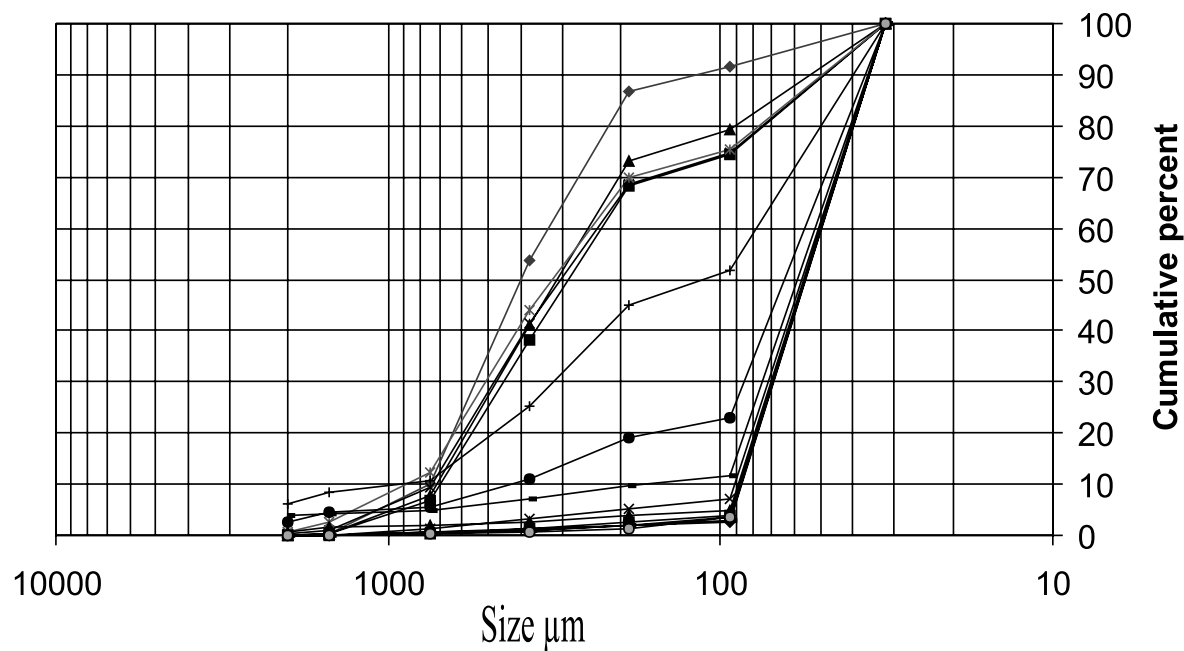

Fig. 2. Sediment grain size for samples from $1 \mathrm{~cm}$ depth intervals (mean positions 3.5-69.5 $\mathrm{cm}$ below the surface, ordered from top to bottom on the graph). Results are shown as cumulative percentage as a function of $\log _{10}$ size, from the largest particle size (left) to the smallest (right).

deviation $\sigma$ ), both the counting statistics of the ${ }^{14} \mathrm{C}$ measurement and the variability of the interval results together make up one measurement. The larger of the two is adopted as measuring uncertainty. To this is added the uncertainty connected with the subtraction of the 'blank'. The quoted $1 \sigma$ uncertainty is, thus, the best estimate for the full measurement and not just based on counting statistics. The results have not been corrected for the reservoir age for UK coastal waters.

\section{RESULTS}

AMS dates

The conventional ages follow a logical sequence down core (Table 2).

\section{Sediment grain size}

The results of analysis at selected depths (Fig. 2) illustrate graphically the change down the long core from a sandy sediment in the top $20 \mathrm{~cm}$ to a clay-dominated sediment beneath, in which $96.6 \mathrm{wt} \%$ is comprised of material of $<63 \mu \mathrm{m}$ in size at the base of the core.

\section{Foraminifera}

The present results combine those obtained from a study of the 0-20 cm section of core MD6a (Murray, 2003b) with those from core MD6 24-70 cm presented here (Fig. 3). It can be seen that the number of benthic tests per g sediment changes dramatically from high values above $35 \mathrm{~cm}$ to low values between $35 \mathrm{~cm}$ and $70 \mathrm{~cm}$. This abundance decrease coincides with the change from sandy muds to grey clay. In the following list, those taxa marked with an asterisk $\left(^{*}\right)$ have no living representatives in the surface sediment and are interpreted as transported (Murray, 2003b). From the sediment surface to $16 \mathrm{~cm}$ the dead assemblages are dominated by the Textularia sagittula group* and Cibicides lobatulus*; from 19-35 cm by Stainforthia fusiformis, Cassidulina laevigata, C. lobatulus*, Hyalinea balthica and Melonis barleeanum; at $44 \mathrm{~cm}$ Elphidium excavatum* reaches values $\geq 10 \%$ and co-dominates with Cassidulina obtusa or Quinqueloculina spp. Analysis of the dataset using multivariate methods shows that the samples form separate clusters and separate fields on PCA and MDS plots (Fig. 4). Clusters A-D are joined at $>60 \%$ similarity, while cluster $\mathrm{E}$ is quite distinct. The first two principal components account for $79 \%$ of the variation and $\mathrm{PC} 3$ for a further $6.9 \%$. PC1 is strongly influenced by Elphidium excavatum with subsidiary Quinqueloculina sp. and Cassidulina obtusa. The key element of PC2, namely the Textularia sagittula group, shows a negative score on PC1. Positive scores on PC2 equate with cluster A and part of C, while positive scores on $\mathrm{PC} 1$ equate with clusters D and E. Cluster B has strong negative scores on PC1 and PC2 and a positive score on PC3. The MDS plot has a very low stress value which indicates that the groupings are sound (Clarke \& Warwick, 1994). All the multivariate plots (cluster, PCA, MDS) show cluster $\mathrm{E}$ to be quite distinct from the rest, with cluster D in an intermediate position. 
Palaeoceanographic history of Muck Deep, Scotland

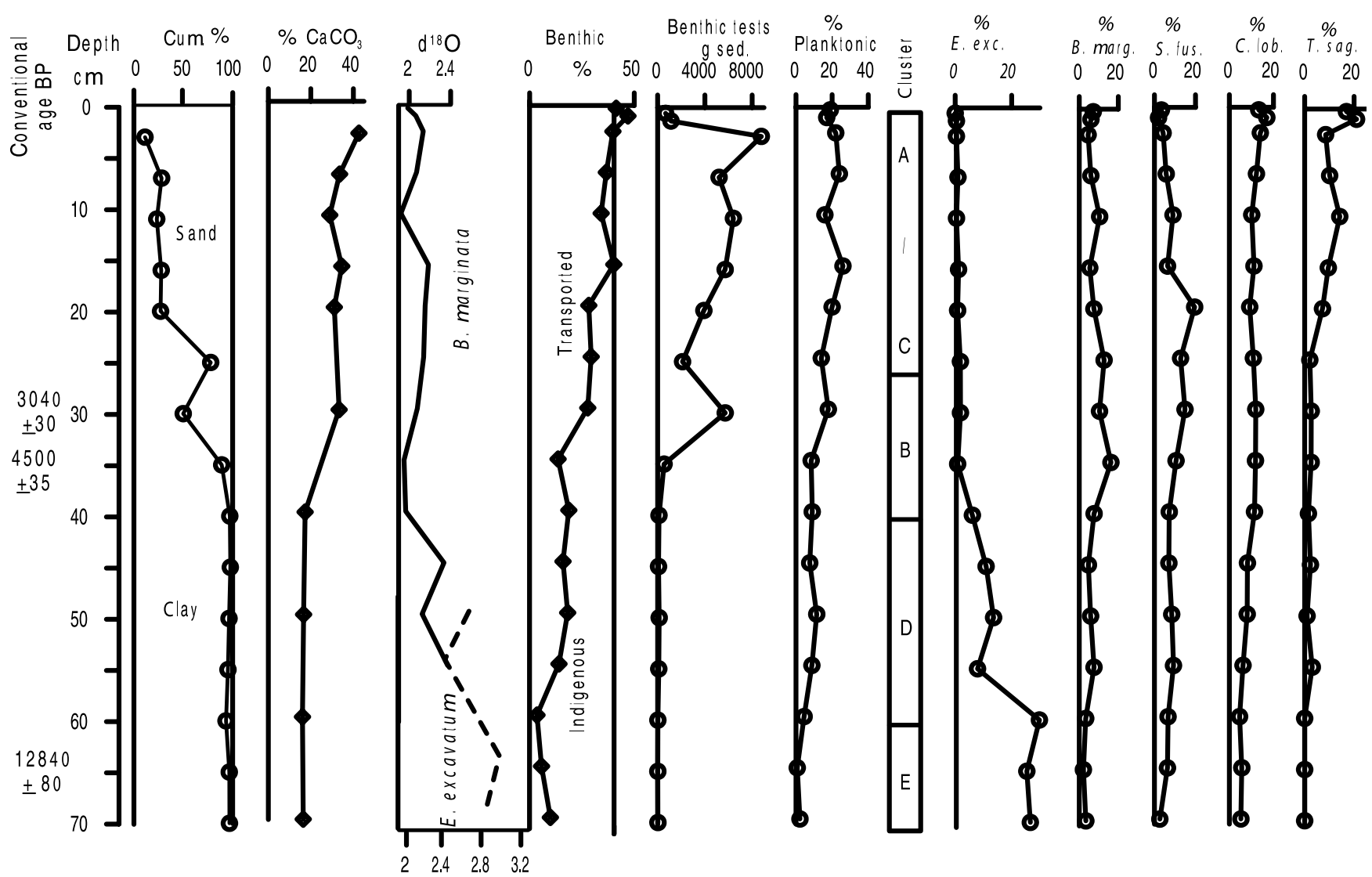

Fig. 3. Foraminiferal results. E. exc., Elphidium excavatum; B. marg., Bulimina marginata; S. fus., Stainforthia fusiformis; C. lob., Cibicides lobatulus; T. sag., Textularia sagittula group.

Species diversity measured by the information function $\mathrm{H}(\mathrm{S})$ and Fisher alpha index shows limited down-core variation (with the exception of an unusually high value of alpha (21) at $2-3 \mathrm{~cm}$; Table 1). Although hyaline forms are dominant throughout (66-90\%), agglutinated forms become abundant (11-28\%) from 0-20 cm, while porcellaneous forms reach higher abundances (9-27\%) from $39-70 \mathrm{~cm}$. The proportion of planktonic tests is higher $(16-26 \%)$ in the upper, more sandy part of the core and decreases downwards to low values $(2-12 \%)$ at the base. Reworked Cretaceous planktonic foraminifera are present in two samples: one individual of Heterohelix at $39-40 \mathrm{~cm}$ and two hedbergellids at $69-70 \mathrm{~cm}$.

\section{Ostracods}

Ostracods are sparsely present in the upper $35 \mathrm{~cm}$ of the succession (0-15 per sample), but somewhat more abundant below this (29-72 per sample). The majority are small juveniles which makes identification more difficult. Rare adult carapaces of Hemicythere villosa, Semicytherura striata, Krithe praetexta, Robertsonites tuberculatus, Nannocythere pavo, Cytheropteron nodosum and Sclerochilus sp. are present.

\section{Stable isotopes}

Both Bulimina marginata and Elphidium excavatum are infaunal. The range of $B$. marginata $\delta^{18} \mathrm{O}$ is $2.098 \pm 0.133$ and, for $E$. excavatum, $2.692 \pm 0.239$. Where both species were measured in the same sample, in one case the values are almost identical
(Table 1, 54-55 cm), whereas in the other there is a $0.505 \%$ difference $(49-50 \mathrm{~cm})$. In E. excavatum, $\delta^{13} \mathrm{C}$ is much more negative than in $B$. marginata.

\section{DISCUSSION}

\section{Age of the sediments}

The conventional ages from the AMS analyses range from 12840 BP from near the base of the core to $3040-4500 \mathrm{BP}$ in the middle of the core (Table 2). The reservoir age for UK coastal waters is $405 \pm 40$ years (Harkness, 1983) but c. 700 years for sediments of Younger Dryas age (Austin et al., 1995). The former is probably more appropriate for the samples discussed here but the correction has not been applied.

\section{Palaeoenvironmental interpretation}

The negative $\delta^{13} \mathrm{C}$ values reflect the infaunal microhabitat of the two species. The $\delta^{18} \mathrm{O}$ record shows a little variation down core and a small offset between species. The possible $0.5-1 \%$ difference in $\delta^{18} \mathrm{O}$ between the base and top of the core is roughly equivalent to a $2-4^{\circ} \mathrm{C}$ cooler temperature (Kim \& O'Neil, 1997).

The interpretation of fossilized assemblages must take into account taphonomic processes. These include loss of tests through destruction and transport of tests either into (gain) or out of (loss) the depositional area. The downward reduction in agglutinated tests could be original or due to their destruction by bacterial decay after burial (Kuhnt et al., 2000). Although 

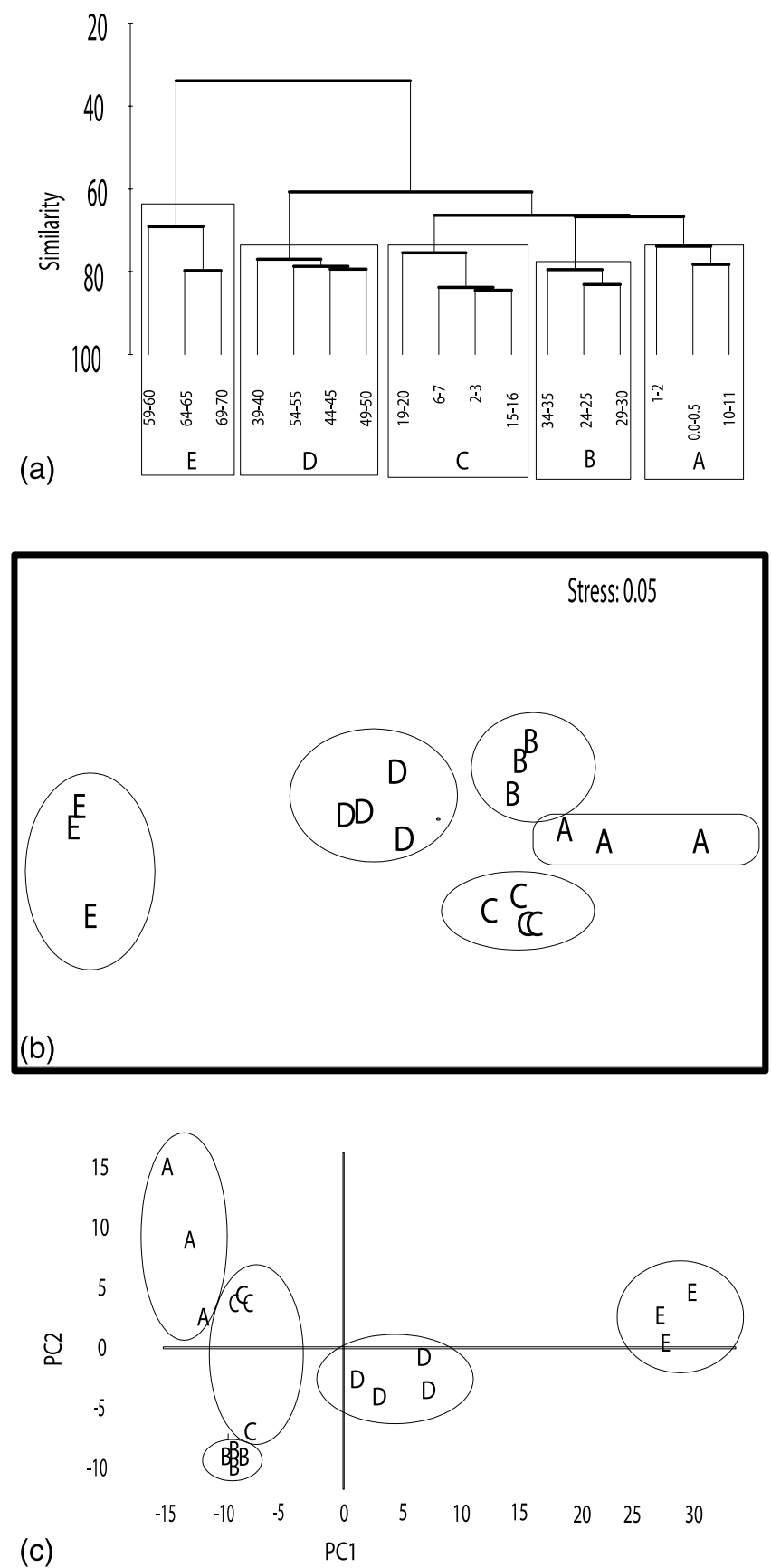

Fig. 4. (a) Cluster analysis of foraminiferal data using Bray-Curtis similarity and no transformation of the data; (b) non-metric MDS plot using the same similarity matrix and the same clusters; (c) PCA without normalization of the data, clusters labelled as in cluster analysis.

some loss may have occurred, it seems likely that most of the change down core is due to the decrease in the transported component which includes forms such as the Textularia sagittula group. There is no evidence of serious loss of calcareous tests through dissolution and the proportion of $\mathrm{CaCO}_{3}$ in the sediment remains significant.

Because the living foraminiferal fauna differed greatly from that preserved dead, the dead assemblages down to $20 \mathrm{~cm}$ were previously interpreted as representing a mixture of indigenous forms (i.e. with living representatives in the surface sediment) and those transported in from the adjacent higher-energy continental shelf (lacking living representatives; Murray, 2003b). This interpretation is probably valid also for the assemblages from $24-25 \mathrm{~cm}$ and $29-30 \mathrm{~cm}$, since these sediments also contain a high proportion of sand. However, below this, the proportion of sand is small and also the number of foraminifera per $g$ sediment is much lower.

The forms inferred to be transported into the area include the Textularia sagittula group and Cibicides lobatulus, both of which have an epifaunal mode of life attached to firm substrates (Pendlebury, 1980; Murray, 1991, 2003a). On death, their tests are detached and transported variable distances, probably mainly as bedload, to be deposited elsewhere. Thus, the assemblages from the surface to $16 \mathrm{~cm}$ (clusters A and C) are characterized by transported forms. Although the area is tidal, tidal currents are weak (maximum during a spring tide $<51 \mathrm{~cm} \mathrm{~s}^{-1}$; Lee \& Ramster, 1981) and the main mechanism for transporting the foraminiferal tests and the sand fraction is thought to be the influence of waves during southwesterly storms (Murray, 2003b). From $19 \mathrm{~cm}$ downwards, the assemblages are dominated mainly by indigenous infaunal taxa such as Stainforthia fusiformis, Cassidulina laevigata, C. obtusa, Hyalinea balthica, Melonis barleeanum, together with epifaunal miliolids. The high abundance of the infaunal species Elphidium excavatum in clusters D and, especially, in E are considered to be indigenous. In Table 1, the proportion of transported tests in samples from 39-70 cm (those with clusters D and E) has been calculated on this assumption. On this basis, the core shows an upward decline in indigenous tests and an increase in transported ones.

At the base of the sequence, clusters $\mathrm{E}$ and $\mathrm{D}$ (with positive scores on PC1) have high species diversity (Fisher alpha 8-15; $\mathrm{H}(\mathrm{S})$ 3.0-3.25) typical of continental shelf seas and continental slope environments of normal marine salinity. With regard to the proportions of the wall structures, although cluster D plots within the range for living assemblages from shelf seas, cluster E has higher values of porcellaneous forms (cf. Murray, 1991, fig. 18.2). Such high diversity assemblages dominated by Elphidium excavatum and miliolids have not yet been reported living and, therefore, their interpretation cannot be made readily against a modern analogue. Assemblages dominated by Elphidium excavatum, from the shallow, vertically mixed waters, of the southern North Sea (23-98 m) have lower diversity (Fisher alpha 3.0-11.5) and the associated species are different, perhaps because the water is much shallower (e.g. Ammonia beccarii, Eggerelloides scaber; Murray, 1992). The Muck Deep assemblages dominated by Elphidium excavatum are composed of species typical of temperate waters, i.e. temperatures above $6-7^{\circ} \mathrm{C}$. Indeed, all the species recorded in the core live in UK waters at present. There is no evidence of the proximity of ice or of cold water. For instance, modern assemblages from near melting ice in Svalbard fjords, with water temperatures of $0-4^{\circ} \mathrm{C}$, contain distinctive cold-water species (Rouvillois, 1966; Korsun \& Hald, 2000), none of which is present in the Muck Deep deposits. Therefore, the E. excavatum fauna must represent a low-energy, sheltered environment with temperatures and salinities similar to those of today. 
Clusters $\mathrm{C}$ and A (positive scores on $\mathrm{PC} 1$ ) have been described previously from this core (Murray, 2003b). These assemblages are considered to represent an almost equal mixture of indigenous forms (mainly free living) and exotic forms (mainly attached) transported in with sand and shell debris from the adjacent higher energy shelf.

Cluster B (negative scores on PC1 and 2) spans the transition from essentially mud sediment below to that with a moderate proportion of sand and a higher content of foraminifera above. The assemblages comprise almost equal proportions of Bulimina marginata, Cibicides lobatulus, Hyalinea balthica, Melonis barleeanum and Stainforthia fusiformis - all, with the exception of $C$. lobatulus, having living representatives in the surface sediments (Murray, 2003b). No living or dead assemblages of this kind have been described previously. However, assemblages dominated by one or other of these taxa are known from temperate European shelf seas (see Murray, 1991, for a summary). In the Celtic Sea it has been shown that $S$. fusiformis is an indicator species for the front between stratified and vertically mixed waters (Scourse et al., 2002). However, this opportunistic species is known to be abundant in other settings, such as ephemerally anoxic fjords and in areas of physical disturbance of the sea floor. Therefore, Alve (2003) suggested that rather than being an indicator of a specific environment this species is primarily an indicator of rapidly changing environmental conditions because of its tolerance of stress.

Planktonic foraminifera do not normally live over continental shelves but their dead tests are commonly transported from the ocean to be deposited in shelf sediments (Murray, 1976). The upward increase in the proportion of planktonic tests in the core could be interpreted as an increase in oceanic influence and/or an increase in water depth.

Although the ultimate source of reworked Cretaceous forms must be Cretaceous deposits, there are no outcrops on the shelf except close to Northern Ireland (Fyfe et al., 1993). The presence of reworked Cretaceous forms in Muck Deep may be a twostage process: glacial erosion of Cretaceous strata (such as those in western Scotland and Northern Ireland; Rawson et al., 1978) during the Quaternary and a further phase of reworking during Holocene erosion of the glacial deposits.

The distributions of modern ostracods in NW European coastal waters have been documented by Athersuch et al. (1989). With the exception of one species, all the ostracods recorded in the core are known to occur in Scottish waters at present, although some are northern forms close to their southern limit (Semicytherura undata, Acanthocythereis dunelmensis, Robertsonites tuberculatus, Elofsonella concinna). However, Hemicytherura clathrata does not live in Scottish waters at present but is found in interglacial and Early Holocene deposits elsewhere in Britain (Whittaker, 1999). It is present in the lowermost two core samples $(64-65 \mathrm{~cm}, 69-70 \mathrm{~cm})$. The abundance of ostracods decreases from shallow to deeper-shelf environments. The dominance of small juveniles with very few adult carapaces suggests that the majority of the ostracods did not live in the depositional area but were transported in as suspension load from elsewhere. Most taxa have depth ranges that are less than the present water depth and probably less than the water depth at the time of deposition of the early part of the sequence. Many are from habitats on macro algae restricted to rocky areas and to the upper part of the photic zone and/or coarse sediment. Juvenile ostracods are readily transported but are fragile and accumulate only under quiet conditions. The paucity of ostracods above $35 \mathrm{~cm}$ in the muddy sands suggests that not only were ostracods rare, but those that may have lived nearby did not survive transport and deposition.

In summary, the environmental changes from the base of the core $(70 \mathrm{~cm}$ to $c .35 \mathrm{~cm}$ ) suggest a progression from low-energy, sheltered, temperate $\left(>6^{\circ} \mathrm{C}\right)$, marine (salinity c. 35) conditions between $c .12000 \mathrm{BP}$ and $c .4500 \mathrm{BP}$, to higher-energy (at least on the adjacent shelf) and slower rate of sediment accumulation in the upper part of the core $(c .35-0 \mathrm{~cm})$. The main potential sources of energy on the continental shelf are currents from tides and disturbance from storm waves from the southwest.

\section{Oceanography - palaeoceanography}

There are no available measurements of tidal currents over Muck Deep but, in a summary of data for British Seas, Lee \& Ramster (1981) give a value of less than $1 \operatorname{knot}\left(51.4 \mathrm{~cm} \mathrm{~s}^{-1}\right)$ for maximum current speed during mean spring tide. From modelling, Pingree \& Griffiths (1980) reported a maximum bottom stress due to $\mathrm{M}_{2}$ and $\mathrm{M}_{4}$ tidal currents of $<20 \mathrm{~Pa}$. During the summer months the waters are stratified (Lee \& Ramster, 1981). On a map of net sand transport directions, Johnson et al. (1982) show no transport in the area of Muck Deep, with a small amount to the north from the island of Col.

The influence of storm waves on the continental shelf is controlled by water depth and wave height and the latter is controlled by direction since only waves from the southwest have a long fetch. Core MD6 was collected from 167-172 m water depth. As noted in the introduction, on the western margin of Scotland climatically induced eustatic changes of sea-level interacted with isostatic changes of the crust as land ice formed during the last glacial event and then melted. Recent studies have shown that the sea-level curve for the Firth of Clyde, which is closest to Muck Deep, falls from around $+35 \mathrm{~m}$ $\mathrm{OD}$ at $14 \mathrm{ka}$ to $+4 \mathrm{~m}$ at $8 \mathrm{ka}$ and rises to $+10 \mathrm{~m}$ at $6 \mathrm{ka}$, since when it has fallen slightly (Lambeck, 1995, fig. 1). A similar pattern is given for Arisaig (Shennan \& Horton, 2002). Ignoring the small amount of sedimentation and assuming no sea floor erosion over the core site, for the past 14-15 ka the water depth has never been less than the present depth and, initially, it was $35 \mathrm{~m}$ deeper $($ c. $205 \mathrm{~m})$. It reached its present depth at around 8-10 ka, deepened slightly to $c .180 \mathrm{~m}$ at $6 \mathrm{ka}$ and then returned to its present depth. It is possible that between $14-15 \mathrm{ka}$ and $10 \mathrm{ka}$, the water depth over the surrounding shelves was deeper than the influence of storm waves and, therefore, there was little or no transport of shelf foraminifera into Muck Deep.

The present wave climate is controlled by gales from the southwest as Muck Deep is sheltered by islands to the west (Outer Hebrides) and the south (Tiree, Coll, Mull). A recent study of wave heights, using satellite altimetry, has shown that the pattern is highly seasonal and inter-annual variability of wave climate is very high over the adjacent Rockall Trough. The increasing wave heights recorded in this area during the latter part of the twentieth century are coincident with the long-term rise in the North Atlantic Oscillation (NAO) index and the two are strongly correlated off west Scotland (Woolf et al., 2002, 2003). Furthermore, a high-resolution record of atmospheric 
circulation over the North Atlantic has been correlated with the ice core records from Greenland (Meeker \& Mayewski, 2002). This shows multi-decadal- and centennial-scale periods (80-110 years) of the intensity of the Iceland low, a key factor in controlling the NAO index. In order to mobilize bottom sediment on the shelf at a water depth of $80 \mathrm{~m}$, a minimum wave height of $10 \mathrm{~m}$ is required and, at present, this may be achieved very rarely (D. K. Woolf, pers. comm. 2002). Nevertheless, it must happen sometimes to cause transport of sand and foraminifera from the shelf into Muck Deep. It is conceivable that, during deposition of the bottom part of the core, the wind and wave direction were not from the southwest and, therefore, waves of sufficient magnitude to mobilize shelf sediment did not affect the area except perhaps once every hundred or more years. Under such conditions, a lower-energy environment would exist over Muck Deep and the adjacent shelf and there would be no transport of sand or foraminifera.

If the water depths over the past $14-15 \mathrm{ka}$ were greater or similar to those at present then the tidal regime may have been similar throughout that time and summer stratification may have been present too. Unpublished tidal modelling for NW European shelf seas shows thermal stratification in this area throughout this period (J. D. Scourse, pers. comm., 2004). Therefore, the likely explanation of the lower energy deposits at the base of the core is related to the impact of storm waves on sediment transport from the adjacent shelves. Either water depths over the adjacent shelves were too great for the sea floor to be influenced by storm waves or the wave climate (direction) differed at that time.

\section{Other records from the NW shelf of Scotland}

On the NW shelf of Scotland there are NE-SW-trending elongate basins filled with $>200 \mathrm{~m}$ of Quaternary deposits. Core MD6 was taken on the flank of an E-W-trending trough that links with one of these. It lies at the boundary between the Jura Formation and sediments labelled 'Quaternary, thin (approximately less than $20 \mathrm{~m}$ ) patchy or absent' on the BGS Tiree sheet (Fyfe et al., 1993). The Jura Formation is postglacial to Holocene and was deposited as the ice retreated and climatic conditions ameliorated. Thus, the basal $35 \mathrm{~cm}$ of core MD6 probably equates with the Holocene top of the Jura Formation, while the upper $35 \mathrm{~cm}$ represents the record of the last 4500 years.

In a borehole from $80 \mathrm{~m}$ of water taken east of the Isle of Lewis, Unit $\mathrm{F}$ records the Holocene events; subunit F1a $(9860 \pm 110 \mathrm{BP})$ is dominated by Elphidium clavatum with Bulimina marginata and this was interpreted as representing a climatic amelioration and deeper water (Graham et al., 1990). The fauna of subunit F1b is similar, while that of overlying unit F2 is dominated by B. marginata with Ammonia batavus, Hyalinea balthica and Nonion (=Melonis) barleeanum. There is some similarity between the F2 fauna and that described from the lower part of core MD6 (cluster E).

\section{SUMMARY AND CONCLUSIONS}

The $70 \mathrm{~cm}$ core from Muck Deep provides a record of microfaunal and palaeoceanographic conditions over the past 12000 years. The foraminiferal record shows that the lower dark-grey clay accumulated under low-energy conditions from around
$12000 \mathrm{BP}$ to around $4500 \mathrm{BP}$, while the upper buff sandy clay accumulated under higher-energy conditions in which sand and foraminiferal tests from the adjacent shelf were transported into the Deep. Sea floor disturbance by waves during southwesterly storms is considered to be the main mechanism of transport at the present time. The much lower level of transported benthic foraminifera in the grey clay suggests that when this was accumulating wave energy was much lower. This could be due to greater water depth or to a change in the direction of the waves. Because of the interplay of eustatic changes of sea-level and glacial rebound, water depth was initially $35 \mathrm{~m}$ greater and has never been less than that of the present day. It is possible that seasonal thermal layering was developed very soon after the ice left the area. Storm waves had little impact on the adjacent shelves and, therefore, did not transport material into Muck Deep, either because the water was too deep or because of a different, more sheltered, wave climate, with prevailing winds coming from a direction other than the southwest.

\section{ACKNOWLEDGEMENTS}

The samples were taken during cruise no. $\mathrm{CH} 143$ of $R V$ Challenger and funded by the NERC Centre for Coastal and Marine Sciences (CCMS). The author thanks Julian Overnell (CCMS) for collecting the cores, John Whittaker (The Natural History Museum, London) who kindly identified the ostracods and provided information on their ecology, Piet Grootes and colleagues at Leibniz Labor, Kiel, for the AMS dates, and various colleagues at Southampton Oceanography Centre: Mike Bolshaw and Helen Coxall for stable isotope analyses, Dave Woolf for discussion about wave climate, Eelco Rohling for discussion on stable isotopes and John Thomson for discussion on AMS dates. James Scourse (Bangor) is thanked for very helpful comments on both earlier and final versions of the manuscript and especially for advice on the effects of eustasy-isostasy on water depths over Muck Deep.

\section{Manuscript received 3 January 2003 Manuscript accepted 28 June 2004}

\section{REFERENCES}

Alve, E. 2003. A common opportunistic foraminiferal species as an indicator of rapidly changing conditions in a range of environments. Estuarine, Coastal and Shelf Science, 57: 501-514.

Athersuch, J., Horne, D.J. \& Whittaker, J.E. 1989. Marine and brackish water ostracods. Synopses of the British Fauna (new Series). Brill, Leiden, 343pp.

Austin, W.E.N. \& Scourse, J.D. 1997. Evolution of seasonal stratification in the Celtic Sea during the Holocene. Journal of the Geological Society, London, 154: 249-256.

Austin, W.E.N., Bard, E., Hunt, J.B., Kroon, D. \& Peacock, J.D. 1995. The ${ }^{14} \mathrm{C}$ age of the Icelandic Vedde Ash; implications for Younger Dryas reservoir age corrections. Radiocarbon, 37: 53-62.

Ballantyne, C.K. 1999. Maximum altitude of late Devensian glaciation on the Isle of Mull and Isle of Jura. Scottish Journal of Geology, 35: 97-106.

Barnett, P.R.O., Watson, J. \& Connelly, D. 1984. A multiple corer for taking virtually undisturbed samples from shelf, bathyal and abyssal sediments. Oceanologia Acta, 7: 399-408.

Binns, P.E., Harland, R. \& Hughes, M.J. 1974. Glacial and postglacial sedimentation in the Sea of the Hebrides. Nature, 248: 751-754.

Bray, J.R. \& Curtis, J.T. 1957. An ordination of the upland forest communities of Southern Wisconsin. Ecological Monographs, 27: 325-349. 
British Geological Survey 1987. Tiree, $56^{\circ} N-08^{\circ} \mathrm{W}$. 1:250 000 Series map, Quaternary Geology. HMSO, London.

Clarke, K.R. \& Gorley, R.N. 2001. Primer v5: user manualltutorial. Primer-E Ltd, Plymouth.

Clarke, K.R. \& Warwick, R.M. 1994. Changes in marine communities: an approach to statistical analysis and interpretation. Plymouth Marine Laboratory, $144 \mathrm{pp}$.

Fyfe, J.A., Long, D. \& Evans, D. 1993. The geology of the MalinHebrides sea area. British Geological Survey, United Kingdom Offshore Regional Report. HMSO, London, 91pp.

Graham, D.K., Harland, R., Gregory, D.M., Long, D. \& Morton, C. 1990. The palaeontology and chronostratigraphy of BGS Borehole No 78/4, North Minch, Scotland. Scottish Journal of Geology, 26: $65-75$.

Harkness, D.D. 1983. The extent of natural ${ }^{14} \mathrm{C}$ deficiency in the coastal environment of the United Kingdom. PACT 8 (Proceedings of the first international symposium on ${ }^{14} \mathrm{C}$ and archaeology, Groningen 1981), 351-364

Haynes, J.R. 1973. Cardigan Bay recent foraminifera. Bulletin of the British Museum (Natural History) Zoology, Supplement 4: 1-245.

Höglund, H. 1947. Foraminifera in the Gullmar Fjord and the Skagerrak. Zoologiska Bidrag från Uppsala, 26: 1-328.

Johnson, M.A., Kenyon, N.H., Belderson, R.H. \& Stride, A.H. 1982. Sand transport. In: Stride, A.H. (Ed.), Offshore tidal sands. Chapman \& Hall, London, 58-94.

Kim, S.T. \& O’Neil, J.R. 1997. Equilibrium and nonequilibrium oxygen isotope effects in synthetic calcites. Geochimica et Cosmochimica Acta, 61: $3461-3475$.

Korsun, S. \& Hald, M. 2000. Seasonal dynamics of benthic foraminifera in a glacially fed fjord of Svalbard, European arctic. Journal of Foraminiferal Research, 30: 251-271.

Kuhnt, W., Collins, E. \& Scott, D.B. 2000. Deep water agglutinated foraminiferal assemblages across the Gulf Stream: distribution patterns and taphonomy. In: Hart, M.B., Kaminski, M.A. \& Smart, C.W. (Eds), Proceedings of the Fifth International Workshop on Agglutinated Foraminifera. Grzybowski Foundation Special Publication, 7: 261-298.

Lambeck, K. 1995. Late Devensian and Holocene shorelines of the British isles and North Sea from models of glacio-hydro-isostatic rebound. Journal of the Geological Society, London, 152: 437-448.

Lee, A.J. \& Ramster, J.W. 1981. Atlas of the seas around the British Isles. Ministry of Agriculture, Fisheries and Food, Lowestoft.

Loeblich, A.R. \& Tappan, H. 1987. Foraminiferal genera and their classification. Van Nostrand Reinhold, New York.

Meeker, L.D. \& Mayewski, P.A. 2002. A 1400 year high-resolution record of atmospheric circulation over the North Atlantic and Asia. The Holocene, 12: 257-266.

Murray, J.W. 1971. An Atlas of British Recent Foraminiferids. Heinemann, London.

Murray, J.W. 1976. A method of determining proximity of marginal seas to an ocean. Marine Geology, 22: 103-119.

Murray, J.W. 1991. Ecology and palaeoecology of benthic foraminifera. Longman, Harlow.
Murray, J.W. 1992. Distribution and population dynamics of benthic foraminifera from the southern North Sea. Journal of Foraminiferal Research, 22: 114-128.

Murray, J.W. 2003a. An illustrated guide to the benthic foraminifera of the Hebridean shelf, west of Scotland, with notes on their mode of life. Palaeontologia Electronica, 5(2): art. 1: 31 pp., $1.4 \mathrm{Mb}$. http.//www-odp.tamu.edu/paleo/2002_2/guide/issue2_02.htm.

Murray, J.W. 2003b. Foraminiferal assemblage formation in depositional sinks on the continental shelf margin west of Scotland. Journal of Foraminiferal Research, 33: 101-121.

Peacock, J.D. \& Harkness, D.D. 1990. Radiocarbon ages and the full-glacial to Holocene transition in seas adjacent to Scotland and southern Scandinavia: a review. Transactions of the Royal Society of Edinburgh: Earth Sciences, 81: 385-396.

Pedersen, T.F., Malcolm, S.J. \& Sholkovitz, E.R. 1985. A lightweight gravity corer for undisturbed sampling of soft sediments. Canadian Journal of Earth Science, 22: 133-135.

Pendlebury, D.C. 1980. Distribution of Recent foraminifera in the Malin Sea - a summary account (prepared by J.R. Haynes). In: Evans, D., Kenolty, N., Dobson, M.R. \& Whittington, R.J. (Eds), The geology of the Malin Sea. Institute of Geological Sciences Report, 79/15: 43-44.

Pingree, R.D. \& Griffiths, D.K. 1980. Sand transport paths around the British Isles resulting from M2 and M4 tidal interactions. Journal of the Marine Biological Association of the UK, 59: 497-513.

Rawson, R.F., Curry, D. \& Dilley, F.C. et al. 1978. A correlation of Cretaceous rocks in the British isles. Geological Society, London, Special Report, 9: 70pp.

Rouvillois, A. 1966. Contribution à l'étude micropaléontologique de la Baie du Roi, au Spitzberg. Revue de Micropaléontologie, 9: 169-176.

Scourse, J.D., Austin, W.E.N., Long, B.T., Assinder, D.J. \& Huws, D. 2002. Holocene evolution of seasonal stratification in the Celtic Sea: refined age model, mixing depths and foraminiferal stratigraphy. Marine Geology, 191: 119-145.

Shennan, I. \& Horton, B.P. 2002. Holocene land- and sea-level changes in Great Britain. Journal of Quaternary Science, 17: 511-526.

Stuiver, M. \& Polach, H. 1977. Discussion: Reporting of ${ }^{14} \mathrm{C}$ data. Radiocarbon, 19: 355-363.

Whittaker, J.E. 1999. Foraminifera and Ostracoda. In: Roberts, M.B. \& Parfitt, S.A. (Eds), Boxgrove. A Middle Pleistocene hominid site at Eartham Quarry, Boxgrove, West Sussex. English Heritage Archaeological Report, 17. English Heritage, London, 163-170.

Williamson, W.C. 1858. On the recent foraminifera of Great Britain. Ray, London.

Woolf, D.K., Challenor, P.G. \& Cotton, P.D. 2002. Variability and predictability of the North Atlantic wave climate. Journal of Geophysical Research, 107(C10): 3145, doi:10.1029/2001JC001124.

Woolf, D.K., Cotton, P.D. \& Challenor, P.G. 2003. Measurements of the offshore wave climate around the British Isles by satellite altimetry. Philosophical Transactions of the Royal Society, A361: $27-31$ 